\title{
Potential Inclusion of Multiple Intelligences in Jordanian EFL Textbooks: A Content Analysis
}

\author{
Taghrid Al-Omari ${ }^{1}$, Ruba Bataineh ${ }^{2}$, Oqlah Smadi ${ }^{2}$ \\ ${ }^{1}$ Jordan University of Science and technology, Irbid, Jordan \\ ${ }^{2}$ Yarmouk University, Irbid, Jordan
}

\begin{abstract}
This study examines the potential incorporation of the principles of the Multiple Intelligences Theory in the Jordanian Action Pack textbook for the first-, fourth-, eighth- and eleventh-grades by means of content analysis. The findings reveal that unlike the moral, existential and spiritual intelligences, which are not incorporated at all, the verbal/linguistic, intrapersonal and spatial/visual intelligences are better represented than other intelligences in the activities of the textbook. The findings further reveal that the incorporation of multiple intelligences is fairly unbalanced among the four levels of the textbook.
\end{abstract}

Key words: content analysis, EFL textbooks, MIT, Multiple Intelligences Theory

\section{Resumen}

Este estudio examina la posible incorporación de los principios de la Teoría de Inteligencia Múltiple en los libros de texto de inglés como lengua extranjera jordanos. Más específicamente, informan sobre un análisis del contenido del libro de texto Action Pack para los niveles primero, cuarto, octavo y undécimo mediante el análisis de contenido. Los resultados revelan que las inteligencias morales, existenciales y las 15 inteligencias espirituales no se encuentran en los libros de texto que se han estudiado. Las inteligencias verbo-lingüísticas, intrapersonales y espacio-visuales están relativamente más incorporadas que otras inteligencias, y que la inclusión de inteligencias múltiples no aparece de forma equilibrada en los cuatro libros de texto.

Palabras clave: análisis de contenido, libros de texto de lengua extranjera, Teoría de la Inteligencia Multiple

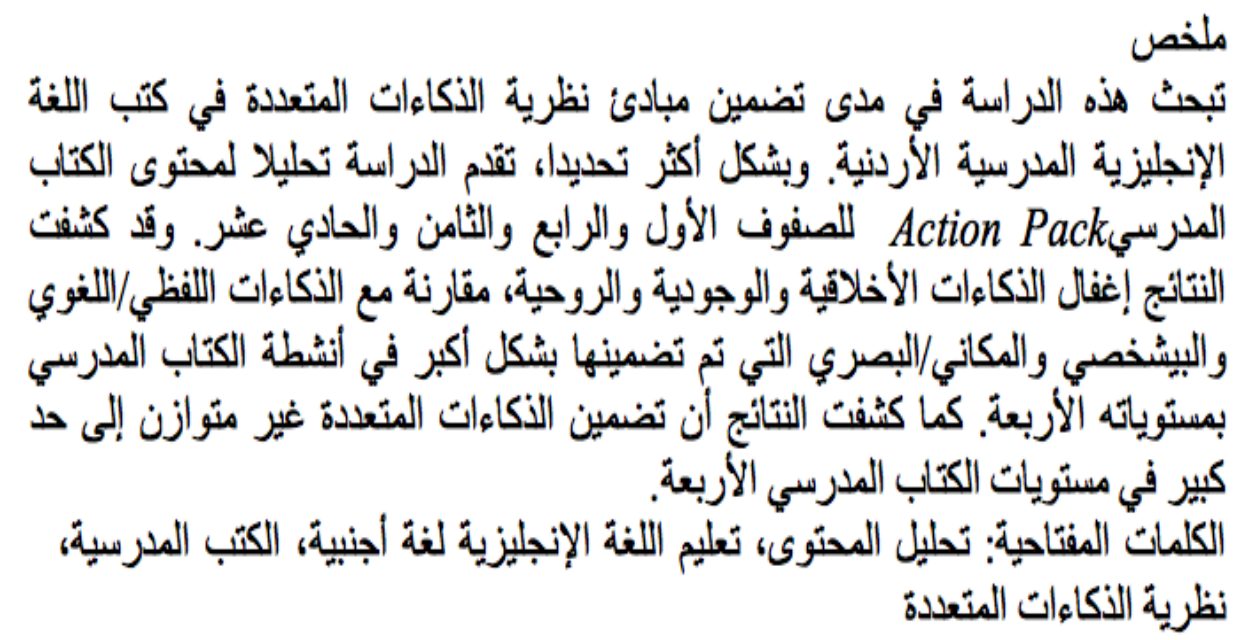




\section{Introduction and Background}

Both the organization of schooling and further education have long been associated with the notion of curriculum. Definitions of curriculum abound (Henson, 1995; Oliva, 1997), as, even though the term is hardly new, the way it is understood has altered over the years. A lot of confusion exists about what is meant by curriculum. Teitlebaum (2008) estimates that over 120 definitions of curriculum exist in the literature. To this effect, Gür (2006) maintains that the definition of curriculum is not only complex but also annoyingly broad, as social, cultural, and economical factors influence it and cause it to vary over time.

Kerr (1968, p. 16) defines curriculum as "all the learning which is planned and guided by the school, whether it is carried out in groups or individually, inside or outside the school". More recently, similar to Kerr's original definition, Wilson (2006, p. 1) defines curriculum as "anything and everything that teaches a lesson, planned or otherwise". She further posits that curriculum has a plethora of types which encompass the overt/explicit/written, societal, hidden/covert, null, phantom, concomitant, rhetorical, curriculum in-use, received, internal, and electronic.

Research suggests that theorists define curriculum in terms of three different dimensions: goals (or what it does or should do), context (or the settings within which it takes shape), and instructional strategy (or the process by which an instructional unit or an entire course is delivered) (Oliva, 1997). Curriculum is often equated with the syllabus of a particular subject and is, thus, limited to a consideration of the content that need be taught. However, it need be viewed more as an educational program, including its philosophy and rationale and the values, attitudes and skills to instill in students, rather than as a collection of subjects.

Ornstein (1994, p. 70) claims that even though little attention is given to the position of the textbook in the process of curriculum making, the curriculum is usually driven by the textbook. He attributes the relatively heavy reliance on the textbook, as well as the workbook, to the traditional view of the written word as the main medium of education.

In the Jordanian educational system, the basic stage encompasses the first through tenth grades. Between 1946 and 1999, English instruction started at the fifth grade (age 10). However, in 2000, the Ministry of Education (MoE) started English instruction in all its public schools from the first-grade (age 6). English is taught as a school subject in four 45- 
minute sessions per week for the first, second, and third grades and five 45-minute sessions per week for the fourth through tenth grades.

The MoE adopted Action Pack, a twelve-level series covering the basic to secondary stages, in phases starting with the academic year 2000 and culminating in 2010 with Action Pack 11 (Haines, 2009) and Action Pack 12 (Haines, 2010) for the eleventh and twelfth grades. Action Pack combines a topic-based approach with functional language practice, careful attention to grammar and vocabulary, and a comprehensive skills syllabus (Lambert, 2008). Each level of Action Pack consists of a pupil's/student's book, a workbook, a comprehensive teacher's book, audio cassettes and a website. Action Pack 1 (Lambert, 2006), Action Pack 4 (Lambert, 2008), Action Pack 8 (Keddle \& Hobbs, 2006), and Action Pack 11 (Haines, 2009) are targeted in this analysis based on the premise that they are fairly representative of the various stages of school education.

The MoE has taken substantial measures to keep its English as a foreign language (EFL) curriculum abreast with the advances in the field, which was manifested in a number of fundamental changes over the last few decades. The EFL curriculum and, consequently, the textbooks taught at Jordanian public schools have been affected by these changes, among the most important of which is the birth of a document, dubbed the General Guidelines and General and Specific Outcomes for the English Language, outlining the learning outcomes for English language teaching (ELT) for grades 1-12 (MoE, 2006). Even though the General Guidelines and General and Specific Outcomes for the English Language (henceforth, GSO) does not endorse any particular method, its pedagogical objectives are quite clear. They emphasize not only life-long learning but also knowledge economy, integration of information and communications technologies (ICTs), new roles for both teachers and learners, varieties of instructional strategies, and new ways of assessing learning.

Although it was not originally designed for use in the classroom, the Multiple Intelligences Theory (MIT), first introduced by Gardner in 1983, has received a lot of attention as a viable educational model. Despite a good share of criticism (Gilman, 2007; O'Shea, 2009; Smith, 2008), the popularity of MIT has skyrocketed since its conception, and it continues to enjoy numerous adaptations in a variety of educational settings. Gardner (2003) himself expressed amazement at how many individuals want to revise their educational practices in light of MIT. 
For the purposes of this research, curriculum refers to the official blueprint designed by the MoE to outline the goals and the organization of the content of teaching English as a foreign language (TEFL) in Jordanian schools. However, textbook, albeit one component of TEFL in the Jordanian school context, is a central component in this research, as it constitutes the ultimate manifestation of curricular (as well as extracurricular) activities. Students spend the bulk of their school day reading, summarizing and discussing textbook content. It is, therefore, crucial to examine which components of MIT are potentially promoted in Jordanian EFL textbooks, represented by those for the first, fourth, eighth, and eleventh-grades.

\section{Problem, Purpose, Question, Significance and Limitations of the Study}

This research follows from the premise that ascertaining which multiple intelligences are actually addressed in MoE-prescribed textbooks is an objective measure of assessing the extent to which these intelligences are promoted in the classroom. That Jordanian teachers exclusively use MoE-prescribed textbooks exposes learners to only the potential content of these textbooks in addition to any incidental extension of this content. The English language, spoken or written, to which learners are exposed is, therefore, quite limited, which further establishes the textbook as the learner's principal EFL resource.

Other factors contribute to this prominence of the EFL textbook as the primary foreign language resource. Aside from the fact that textbooks are prescribed by the MoE to take center stage in all classroom activities, teachers are required to teach the entire textbook within the school year. This is often compounded by large class size (often as many as 55 students per class) and excessive teacher work load (as many as 28 hours a week). This is not exclusive to Jordan but is rather common in other parts of the world, as reported by Sinclair and Renouf who claim that

[m]ost language teachers, however, do not have the choice, but are obliged to use a textbook and nothing else. This state of affairs is dictated often by economics, sometimes by politics and religion, sometimes by educational tradition or bureaucracy. In our experience, there is generally very little resentment from the teachers, because the language they have to teach is quite tidily presented through a textbook, particularly if it has been specially composed for them. (1988, p. 3)

Generally speaking, the focus of this research is three-fold: identifying the multiple intelligences addressed in the activities of the textbooks under study, assessing the frequency of occurrence for each of these intelligences, and judging this frequency relative to the overall 
occurrence of all intelligences in each of the four textbooks to establish whether or not this inclusion is balanced.

Inasmuch as these intelligences are incorporated in the textbooks, in conjunction with GSO, this study is also a preliminary assessment of the MoE's commitment to innovative pedagogical practice. English is a required subject throughout the twelve years of schooling in Jordan, where the learners' first official exposure to EFL instruction starts in the first-grade.

To the researchers' best knowledge, Jordanian EFL textbooks have never been content analyzed for multiple intelligences. Thus, this study attempts to find out the extent to which the Jordanian EFL curriculum, represented by Action Pack textbooks for the first, fourth, eighth, and eleventh-grades, incorporate MIT. More specifically, this study seeks to answer the question, to what extent does the Jordanian EFL curriculum, represented by Action Pack textbooks for the first, fourth, eighth and eleventh-grade, incorporate multiple intelligences in its content?

Even though MIT has grabbed the attention of many educators worldwide, the researchers did not come across any study that considers its inclusion in the teaching material in the Arab world. This is further evidenced by the fact that none of the Arab countries appeared within the countries mentioned by Chen, Gardner, and Moran (2009) in their Multiple Intelligences Theory around the World, a book which compiles stories from MI practitioners worldwide who not only address the implementation of MIT in their respective countries but also discuss some of the cultural challenges they faced along the way.

The current content analysis of Action Pack series is hoped to bridge part of this gap in the literature and add to the existing literature on the inclusion of MIT in the activities of this series. A number of pedagogical implications, from which EFL teachers can benefit, are also presented.

Given that the content analysis is restricted to the four textbooks under study, it should be seen as a preliminary inquiry into the incorporation of multiple intelligences in Jordanian EFL textbooks. More input may be needed in terms of content analyses of other textbooks in the Action Pack series and, probably, additional input from students, teachers and other stakeholders.

\section{Review of Related Literature}

Some scholars (see, for example, Russell \& Norvig, 2009) believe that being intelligent is not restricted to the academic domain but is rather an umbrella term used to describe a property of 
the mind that encompasses many related abilities, such as the capacities to reason, plan, solve problems, think abstractly and learn. Intelligence may also include traits like creativity, personality, character, knowledge or wisdom.

However, dissatisfaction with traditional paper and pencil versions of IQ and Scholastic Aptitude tests was mainly the result of their inability to predict success outside school or determine what is exactly meant by intelligence, which has eventually led to the development of a number of alternative theories, such as the MIT, which suggests that intelligence is the result of a number of independent abilities, dubbed 'multiple intelligences' (Gardner, 2004), rather than a singular, static and inherited characteristic (Botelho, 2003; Thompson, 2009) which uniquely contribute to human performance, and that standardized tests are limited with their almost exclusive stress on linguistic and logical skills (Gardner \& Hatch, 1996).

Gardner (2006, p. 5) defines intelligence as "a pluralistic view of mind, recognizing many different and discrete facets of cognition, acknowledging that people have different cognitive and contrasting strengths and contrasting cognitive styles". He argues that, with proper remediation, most students could catch up and perform quite well in school regardless of their background. In fact, Gardner (2006, p. 3) maintains that "[j] ust as you could measure someone's actual or potential height, now, it seems you could measure someone's actual or potential intelligence".

Gardner (2004, p. xxxii) further posits that there is "a multitude of intelligences which are quite independent of each other and that each intelligence has its own strengths and constraints". Gardner's original MIT started out with seven intelligences: verbal/linguistic, logical/mathematical, spatial/visual, bodily/ kinesthetic, musical, interpersonal, and intrapersonal. Briefly defined, the verbal/linguistic intelligence involves sensitivity to spoken and written language, the ability to learn languages, and the capacity to use language to accomplish certain goals whereas the logical/mathematical intelligence is realized in the ability to analyze problems logically, carry out mathematical operations, and investigate issues scientifically. The musical intelligence, which Gardner claims runs quite parallel to verbal/linguistic intelligence, involves skill in the performance, composition, and appreciation of musical patterns. The bodily/kinesthetic intelligence entails one's potential to use the whole or parts of one's body to solve problems while spatial/visual intelligence involves the potential to recognize and use the patterns of wide space and more confined areas. The interpersonal 
intelligence involves the ability to understand other people's intentions, motivations and desires while the intrapersonal intelligence entails the capacity to understand oneself and to appreciate one's feelings, fears and motivations. Table 1 below summarizes the capabilities and perceptions involved in each of the original seven intelligences.

Table 1. Capabilities and Perceptions of the Original Seven Components of MIT*

\begin{tabular}{c|c}
\hline Type of Intelligence & Capability and Perception \\
\hline Verbal/Linguistic & words \\
\hline Logical/Mathematical & logic and numbers \\
\hline Musical & music, sound, and rhythm \\
\hline Bodily/Kinesthetic & body movement control \\
\hline Spatial/Visual & images and space \\
\hline Interpersonal & other people's feelings \\
\hline Intrapersonal & self-awareness \\
\hline
\end{tabular}

* adapted from Chapman (2009)

Gardner (1999) discusses four additional intelligences (viz., spiritual, moral, existential, and naturalist) but seems to only settle on existential and naturalist intelligences. Existential intelligence relates to the ability to contemplate phenomena or questions beyond sensory data whereas naturalist intelligence involves nurturing and relating information to one's natural surroundings. Nonetheless, spiritual and moral intelligences, even though seemingly not endorsed by Gardner, have managed to find a place in the literature. Spiritual intelligence involves one's capacity to grasp cosmic and transcendent truths while moral intelligence relates to the ability to differentiate right from wrong as defined by universal principles, as shown in Table 2 below.

Table 2. Capabilities and Perceptions of the Additional Four Components of MIT*

\begin{tabular}{c|c}
\hline Type of Intelligence & Capability and Perception \\
\hline Existential & 'ultimate issues' \\
\hline Naturalist & natural environment \\
\hline Spiritual & religion \\
\hline Moral & ethics, humanity, and value of life \\
\hline
\end{tabular}

* adapted from Chapman (2009)

MIT has recently been considered in TEFL. Berman (2005), who claims that MIT can profoundly affect how teachers view their pupils, illustrates a variety of exercises, activities and tasks which can be used in the EFL classroom. MIT posits that students would learn 
better when teachers use different methods, exercises, and activities to reach all students, not only those who excel at linguistic and logical intelligence. To this effect, Arnold and Fonseca maintain that

[1]anguage learning can be supported by bringing in the musical, visual-spatial, bodily-kinesthetic, interpersonal, intrapersonal, mathematical and naturalistic abilities as they constitute distinct frames for working on the same linguistic content. Not only does this variety of presentations allow students to learn in their own best ways, it also helps to reduce boredom as language learning requires frequent circling back over the same material if learning is to be sustained. (2004, p. 7)

Armstrong (2001) suggests that MIT is remarkable in its provision of different potential pathways to learning, which is further corroborated by Nolen (2003) who maintains that the presentation of EFL materials should engage all or most of the intelligences as each is potentially present in every learner. If a teacher is having difficulty reaching a student through more traditional methods of instruction, MIT puts forth several instructional alternatives to facilitate learning. However, Gardner (2003) warns that MI should not constitute an educational goal in itself but rather a catalyst through mobilizing several intelligences to help achieve that goal. He (in Weiss, 1999) urges teachers to take learners' individual differences very seriously. However, scholars (see, for example, Berman, 2005; Moran, Kornhaber \& Gardner, 2006; Heacox, 2002; Nolen, 2003) maintain that, to do so, teachers do not need to create nine different lesson plans, for it would be painfully impractical to plan individual lessons for each learner, but rather to design rich learning experiences that nurture each learner's combination of intelligences.

The fact that the intelligences discussed in this research are presented as separate entities does not by any means suggest that they are divisible entities. Other than the manageability of the presentations, the researchers are aware of the intricate relationships between these intelligences, more for some than others. For example, albeit beyond the scope of this study, the researchers are aware of the relationship between language and music and, thus, the potential links between the verbal/linguistic intelligence and musical intelligence. Musical intelligence has been linked to literacy and linguistic skills, social skills, and selfexpression (Fonseca-Mora, Toscano-Fuentes \& Wermke, 2011; Schellenberg, 2005; Sleve \& Miyake, 2006). Along the same lines, Shabani and Torkeh (2014) suggest not only a relationship between musical intelligence and language learning but also a facilitative effect for musical intelligence on foreign language learning. 
More generally, a growing body of research (for example, Anvari, Trainor, Woodside \& Levy, 2002; Hurwitz, Wolff, Bortnick \& Kokas, 1975; Lyons, 2008; Patel, 2008 \& 2012; Patel \& Iversen, 2007) suggests a facilitative effect for music on language learning. The integration of music into the language curriculum is reported to develop auditory skills (Gromko, 2012), phonemic awareness and overall language skills (Lyons, 2008), phonological awareness and word recognition skills (Anvari et al, 2002; Bolduc, 2009; Bolduc \& Montesinos-Gelet, 2005), reading comprehension (Hurwitz et al, 1975), and emergent literacy (Bolduc, 2009; Gromko, 2012; Register, 2001).

The researchers were able to locate only few content analysis studies on the inclusion of MI principles in EFL textbooks, probably because textbook analysis in light of MIT is a rather recent endeavor. Palmberg (2002) examined the intelligence profile of Bricks 1 textbook used at the lower level in Finland. The analysis revealed that $97 \%$ of the 300 exercises of the textbook were categorized as verbal/linguistic, $76 \%$ intrapersonal, $25 \%$ interpersonal, $8 \%$ logical/mathematical, $5 \%$ bodily/kinesthetic, $5 \%$ spatial $/$ visual, $3 \%$ naturalistic, 2\% musical, and 0\% existentialist. Similarly, Snider (2001) analyzed ten firstyear college German textbooks to determine the types of activities and how they engage learners' multiple intelligences. The texts were found to use forty-one types of MIT-oriented activities of which thirty engage verbal/linguistic intelligence.

Along the same lines, Botelho (2003) content analyzed six textbooks to determine how their activities help enhance Brazilian EFL learners' intelligences. She found that $75 \%$ of the activities mainly cater for the verbal/linguistic, intrapersonal, spatial/visual, and interpersonal intelligences. The logical/mathematical, bodily/kinesthetic, musical/rhythmic, naturalist, and existential intelligences were observed in less than $40 \%$ of the activities of the six books.

Research has reported that MIT potentially fosters students' learning (see, for example, Haley, 2004; Hamurlu, 2007). This research has unanimously reported that MITbased instruction not only increased students' achievement in English classes but also had positive effect on their attitudes towards the content.

\section{Method and Instrumentation}

This study uses content analysis to determine the potential inclusion of Gardner's verbal/linguistic, logical/mathematical, spatial/visual, bodily/kinesthetic, musical/rhythmic, interpersonal, intrapersonal, naturalist, moral, spiritual, and existential intelligences in the 
activities of the Action Pack textbooks for the first-, fourth-, eighth- and eleventh-grades, selected as representative samples of the twelve-book series. All the activities of the four textbooks were closely examined to identify the potential incorporation of each of the eleven intelligences. The analysis was conducted along the criteria of incorporation, distribution and balance of the various intelligences in these activities. The unit of analysis was the activity and the category of analysis was the type(s) of intelligence in each of the activities in the four textbooks.

To establish the validity of the list of activities used in the analysis, it was given to a jury of three experts in TEFL and measurement and evaluation to ascertain its appropriateness for the purposes of the research. The jury's feedback, which constituted of suggestions to rephrase, add or delete items, was used to modify the list prior to the analysis. Intra-rater reliability of the content analysis was also ascertained through test-retest. The activities were initially analyzed and reanalyzed three weeks later according to the categories of the analysis by the second researcher. The reliability co-efficient between the two analyses was calculated and found to amount to 0.99 . Moreover, two other independent analyses were conducted to ascertain inter-rater reliability: one by a graduate student from the Department of Translation and another by an instructor at the Language Center at Yarmouk University who studied content analysis and did some work in this area. The inter-rater reliability coefficients between the analyses of the researcher and the first analyst, the researcher and the second analyst, and the two analysts themselves were found to be $0.99,0.991$ and 0.98 , respectively.

\section{Findings and Discussion}

To answer the research question, to what extent does the Jordanian EFL curriculum incorporate the principles of MIT?, the researchers analyzed the content of the student books of the Action Pack series for the first-, fourth-, eighth- and eleventh-grades in light of MIT principles. The frequency of the Multiple Intelligences in all activities in the four textbooks under study was calculated, as shown in Table 3 (next page). 
Table 3. Frequency of the Activities which Incorporate MI in the Four Textbooks

\begin{tabular}{|c|c|c|c|c|c|c|c|c|c|c|c|}
\hline \multirow[b]{2}{*}{ Book } & \multicolumn{11}{|c|}{ Dimension } \\
\hline & 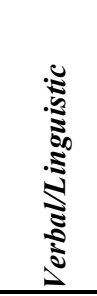 & 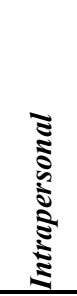 & 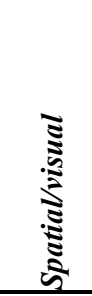 & 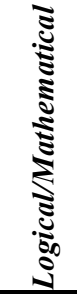 & 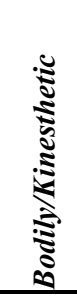 & 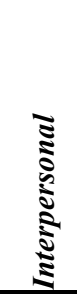 & 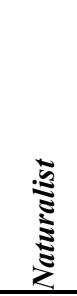 & 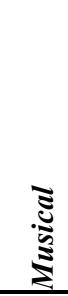 & $\frac{\mathfrak{s}}{\mathfrak{s}}$ & 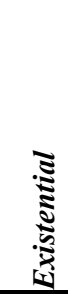 & 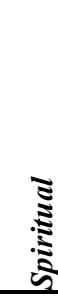 \\
\hline Eleventh & 370 & 277 & 122 & 150 & 147 & 91 & 29 & 1 & 0 & 0 & 0 \\
\hline$\%$ & 100.0 & 74.9 & 33.0 & 40.5 & 39.7 & 24.6 & 7.8 & 0.3 & 0.0 & 0.0 & 0.0 \\
\hline Eighth & 255 & 200 & 87 & 117 & 99 & 62 & 35 & 1 & 0 & 0 & 0 \\
\hline$\%$ & 100.0 & 78.4 & 34.1 & 45.9 & 38.8 & 24.3 & 13.7 & 0.4 & 0.0 & 0.0 & 0.0 \\
\hline Fourth & 126 & 76 & 126 & 58 & 6 & 50 & 47 & 5 & 0 & 0 & 0 \\
\hline$\%$ & 100.0 & 60.3 & 100.0 & 46.0 & 4.8 & 39.7 & 37.3 & 4.0 & 0.0 & 0.0 & 0.0 \\
\hline First & 94 & 30 & 94 & 43 & 76 & 66 & 13 & 9 & 0 & 0 & 0 \\
\hline$\%$ & 100.0 & 31.9 & 100.0 & 45.7 & 80.9 & 70.2 & 13.8 & 9.6 & 0.0 & 0.0 & 0.0 \\
\hline Total & 845 & 583 & 429 & 368 & 328 & 269 & 124 & 16 & 0 & 0 & 0 \\
\hline$\%$ & 100.0 & 69.0 & 50.8 & 43.6 & 38.8 & 31.8 & 14.7 & 1.9 & 0.0 & 0.0 & 0.0 \\
\hline
\end{tabular}

* calculated relevant to the total number of activities $(\mathrm{n}=370)$

Table 3 shows that unlike the moral, existential and spiritual intelligences which have a zero frequency of incorporation in the activities of the four textbooks under study, the verbal/linguistic, intrapersonal and spatial/visual intelligences are heavily incorporated with $100 \%, 69 \%$, and $50 \%$, respectively. On the other hand, the logical/mathematical, bodily/kinesthetic, interpersonal, naturalist, and musical/rhythmic intelligences are moderately incorporated with $44 \%, 39 \%, 32 \%, 15 \%$, and $2 \%$, respectively.

More specifically, the verbal/linguistic and intrapersonal intelligences in the eleventhgrade textbook are fairly well incorporated with percentages of 100 and 75, respectively. On the other hand, the percentages of the logical/mathematical, bodily/kinesthetic, spatial/visual, interpersonal, naturalist and musical/rhythmic intelligences ranged between just under one to 41. In other words, the intelligences in this textbook were presented in terms of frequency of inclusion as verbal/linguistic, intrapersonal, logical/mathematical, bodily/kinesthetic, spatial/visual, interpersonal, naturalist, and musical/rhythmic.

As for the eighth-grade textbook, the verbal/linguistic and intrapersonal intelligences are the most dominant, with percentages of 100 and 79, respectively, as opposed to all other intelligences whose percentages of inclusion ranged between just under one and 46. The order 
of occurrence of the other intelligences in eighth-grade textbook was verbal/linguistic, intrapersonal, logical/mathematical, bodily/kinesthetic, spatial/visual, interpersonal, naturalist, and musical/rhythmic.

The verbal/linguistic, spatial/visual, and intrapersonal intelligences in the fourth-grade textbook were fairly well represented with percentages of 100, 100, and 60. Meanwhile, the other intelligences were not as well represented since their percentages ranged between four and 46. The inclusion of these intelligences in fourth-grade textbook proceeded from the verbal/linguistic and spatial/visual, intrapersonal, logical/mathematical, interpersonal, naturalist, and bodily/kinesthetic to the musical/rhythmic.

The verbal/linguistic, bodily/kinesthetic, spatial/visual, and interpersonal intelligences in the first-grade textbook were well represented with percentages of 100, 100, 81, and 70 whereas the other intelligences were not as well represented with percentages that ranged between 10 and 46. The intelligences in this textbook were presented in descending order of frequency as verbal/linguistic, spatial/visual, bodily/kinesthetic, interpersonal, logical/mathematical, intrapersonal, naturalist, and musical/rhythmic.

It should be clear right from the beginning that although GSO attempts to incorporate various recent teaching and learning theories and approaches, no reference was made to MIT. In other words, GSO does not make any specific reference to MIT despite the vast amount of interest it has generated in the mid 1980s. MIT has been applied in homes, schools (at all levels), community and adult training programs all over the world since 1987. However, surprisingly, GSO does not make any reference to MIT, which may indicate that the inclusion of MIT in the four textbooks was incidental at best.

In other words, Multiple Intelligences are incorporated in the activities of the textbooks probably because GSO (MoE, 2006, p. 11) posits that "English language teaching should be interactively attempted in light of the basic principles of communicative language teaching" which stipulate that "activities and strategies for learning are varied according to learner preferences and needs" (Omaggio, 2001, p. 117), which may explain the findings of the content analysis in terms of the incorporation of multiple intelligences in the textbooks under study. Eight intelligences (verbal/linguistic, spatial/visual, intrapersonal, bodily/kinesthetic, interpersonal, logical/ mathematical, naturalist and musical/rhythmic) were evident, to various degrees, in the four textbooks under study. Only three intelligences (moral, spiritual and existential) were not incorporated in the activities of the four textbooks, which 
may be readily attributed to the fact that the Action Pack series is written by non-Jordanian authors who may not have been keen enough to represent the Arab/Islamic ideals in the English curricula.

It is worth noting in this regard that GSO (MoE, 2006, p. 9) also relates both utilizing critical thinking skills and appreciating other cultures to the Arab-Islamic culture as core subject outcomes. It posits that "after learning English at school, students will have deepened their values and heritage". However, these outcomes could hardly be achieved without exposing students to learning material that pertains to such issues.

As learners under the umbrella of Communicative Language Teaching (CLT), Jordanian students should be able, at a certain level of proficiency, to talk about their values and heritage. Students who have the moral and/or spiritual intelligences need to be exposed to activities that cater for these intelligences, which is lacking in the textbooks under study. The absence of the existential intelligence from the activities may be attributed to the complex and controversial nature of the issues associated with it, which may be inappropriate for the students' age or level of proficiency. This conclusion is consistent with that of Botelho (2003) who attributed the infrequency of occurrence of the existential intelligence to its complex domains such as philosophy, religion and mysticism.

It is safe to conclude that the inclusion of multiple intelligences in the four textbooks is both accidental and erratic. This could be attributed to the fact that MIT is not even mentioned once in the GSO, which may also provide further evidence that the Jordanian EFL curriculum is not designed with an eye on MIT. However, this is far from peculiar to Jordan, as it is consistent with reports from other countries (see, for example, Botelho's (2003) on Brazilian EFL/ESL textbooks).

The verbal/linguistic and intrapersonal intelligences were dominant in the eighth- and eleventh-grade textbooks, which is consistent with Palmberg (2002) who reported that Bricks was predominantly verbal/linguistic and intrapersonal and partially with Snider (2001) who found that the vast majority of the activities in ten German college textbooks engage the verbal/linguistic intelligence. On the other hand, the verbal/linguistic, intrapersonal, and spatial/visual intelligences were dominant in the fourth-grade textbook whereas verbal/linguistic, spatial/visual, bodily/kinesthetic and interpersonal intelligences were dominant in the first-grade book. 
The verbal/linguistic intelligence was present, in mounting complexity, in all the activities of the four textbooks under study. For example, first-grade students are asked right from the start to listen and point (pp. 4, 6, 7, 8 and 11) and, at a later point, to point and say (pp. 17, 20, and 33), ask and answer (pp. 23 and 24) and to sing (pp. 5, 13 and 23). Similarly, fourth-grade students are asked to listen and read (pp. 8, 12, 16, 19, 23, 27, 31 and 38), ask and answer (pp. 10, 14, 17 and 18), read and say (p. 7), listen and answer (p. 17), tell the story (p. 32) and talk (p. 36).

Similarly, eighth-grade students are also exposed to a variety of activities that aim at developing their linguistic competence. See, for example, listen and read about the students (Activity 4, p. 7), talk about sports, ask and answer questions about students (Activity 7, p. 7) and read the article again (Activity 4, p. 9). By the same token, eleventh-grade students are asked to read the article about the two festivals quickly to find the answers (Activity 2, p. 15), listen again and answer these questions (Activity 2, p. 16) and discuss these questions with a partner (Activity 2, p. 17).

The superior attention given to the verbal/linguistic intelligence is an expected result since language textbooks usually integrate the reading, writing, speaking and listening skills that depend mainly on this intelligence. Developing students' linguistic competence is the main aim of teaching a foreign language, which is hardly achievable without capitalizing on the verbal/linguistic intelligence. This attention can also be attributed to the fact that GSO is based on the communicative approach where "communicative competence, with an emphasis on fluency and acceptable language use, is the goal of instruction" (Omaggio, 2001, p. 117).

Before the discussion goes any further, it is worth noting that the same activity may cater for more than just one intelligence. For example, read and choose (fourth-grade textbook, Activity 6, p. 37) asks the students to express whether they want to have a quiet holiday, see some beautiful animals and birds, or ride a camel after reading a little information about Wadi Rum (Jordan) and, thus, at once engaging the verbal/linguistic, naturalist, spatial/visual and intrapersonal intelligences. Some activities require individual tasks before the pair or group work is introduced or vice versa. For example, in the eleventhgrade textbook, (activities 1 and 2, p. 17), look at these sentences... discuss these questions with a partner, the activity asks students to perform both individually and in pairs.

The results also revealed that the intrapersonal intelligence is fairly well represented in the fourth, eighth and eleventh-grade textbooks. It appears in the activities that require tasks 
with individual elements such as doing things by oneself, reflecting, talking about oneself and giving personal opinions. For example, in the fourth-grade textbook, students are asked to do some activities individually such as listen and choose (Activity 2, p. 28) and right or wrong (Activity 7, p. 37). By the same token, the eighth-grade textbook has some activities such as write about your experiences (Activity 6, p. 34), read the webpage and answer the questions (Activity 6, p. 37) and write a paragraph about your life (Activity 8, p. 38). Similarly, in the eleventh-grade textbook, students are exposed to some activities such as copy and complete this short story (Activity 1, p. 17) and listen again and answer these questions (Activity 2, p. $16)$.

The large number of activities in the fourth, eighth, and eleventh-grade textbooks, which aim at intrapersonal intelligence probably stems from the rationale for teaching EFL in Jordan as students "need to acquire a sufficient knowledge of English [...] to utilize [...] when doing their projects, reports, research papers [... and] to be able to express oneself" (MoE, 2006, p. 9). Students are reportedly encouraged to use the language in authentic real life situations to be able to express and understand themselves, their strengths, weaknesses, moods, desires and intentions.

The spatial/visual intelligence is well represented in the first and fourth-grade textbooks. In both textbooks, each activity is accompanied by illustrative pictures so much so that the number of activities equals the number of pictures. For example, in the first-grade textbook, pictures of classroom objects appear on pages 8, 9, 10, 11 and 15 whereas, in the fourth-grade textbook, pictures of various types of birds, fish and animals, appear on pages 41, 43 and 44 respectively. Tables, graphs, maps and charts are also evident in these textbooks. For example, in the fourth-grade textbook, tables are presented on pages 10, 14 and 24 .

That the spatial/visual intelligence is dominant in the first and fourth-grade textbooks is most probably because foreign language textbooks rely heavily on pictures and illustrations to support content such as dialogues, reading texts, listening activities and vocabulary items especially at early stages and young ages where the learners' linguistic competence is not yet developed. This is consistent with Botelho (2003) who concluded that more visual input is evidently offered to young EFL learners.

The bodily/kinesthetic and interpersonal intelligences are also fairly well represented in the first-grade textbook which is consistent with research findings that the younger the 
learners, the more physical activities they tend to need (See, for example, Bas, 2008). EFL learners at this early stage need to learn by experience and doing, simply because they easily lose interest after a short time. Wright, Betteridge and Buckby (2005) report that games help and encourage learners to sustain their interest and work. For example, in first-grade textbook, as students are taught to introduce themselves, they are asked to stand up (p. 6), wave their hands as they say hello (p. 6) and stand up and sit down (p. 7). In other words, they are encouraged to develop their ability to use their body to express ideas and feelings, which lies at the heart of the bodily/kinesthetic intelligence.

Learning through interaction with others can be achieved by activating the interpersonal intelligence. EFL learners at this early stage need a model to imitate, interact with and get feedback from. In this case, the teacher is most likely the only live model in addition to peers and any other resource persons called on by the teacher or the school. To illustrate, the content of the first-grade textbook is presented mainly in dialogue form between two students e.g., Hello, Faisal; Hello, Laila (p. 6), what's this? It's a pencil (p. 9) and games that involve a group of students e.g., in Dan's game (p. 11), a group of students plays a game that has to do with colors: let's play.., a pencil.., green..., red.., a book..., blue..., a ball (Activity 4, p. 11).

The importance given to the interpersonal intelligence is also in line with GSO which posits that ELT should be interactively attempted and evaluated in light of CLT. One of the major principles of CLT is to encourage learners to communicate and interact with others (Omaggio, 2001).

The musical/rhythmic, logical/mathematical and naturalist intelligences were relatively less represented in the four textbooks, but they were evident in some modules. For example, there were nine songs in the first-grade textbook, five songs in the fourth-grade textbook, one in the eighth-grade textbook and one in the eleventh-grade textbook. This is consistent with other research findings (see, for example, Botelho, 2003) who found that the musical/rhythmic intelligence was among the less common intelligences in language textbooks. The distribution of this intelligence among the four textbooks is essentially balanced. It seems that the authors of Action Pack believe that songs are more appropriate for younger learners. Nevertheless, songs can be used both as a teaching aid and an entertainment tool to strengthen both the musical and verbal/linguistic intelligences at any learning stage, 
especially for learners who are sensitive to rhythm, pitch and melody (see, for example, Stansell, 2005).

The inclusion of the naturalist intelligence is often driven by the topic of the module. For example, the fourth-grade textbook (Activity 6, p. 41) shows pictures of the bee-eater, sunbird, falcon and hoopoe for students to compare birds. In the eighth-grade textbook (Module 2, Focus on the Environment, Deserts, p. 24), students are asked to read about the top five deserts, sand dunes, an oasis in the Sahara desert and the fringe-toed sand lizard. Similarly, as students are expected to guess, reason, and think critically, the logical/mathematical intelligence was found in a few modules. For example, in the first-grade textbook, students are asked to play a guessing game (Activity 2, p. 27). In the fourth-grade textbook, students are asked to listen and match (pp. 66 and 70), and in the eighth-grade, students are asked questions like what can you remember and what do you think (Module 3, How we Live, p. 41), which all help students build their cognitive abilities to reason, predict and analyze.

\section{Conclusion and Recommendations}

The findings suggest that the actual incorporation of multiple intelligences not only lags behind the theoretical stipulations of the curriculum but also suggests lack of systematic attention to the equitable exposure of learners to these intelligences. Further research in this vein, particularly a full scale investigation of textbook content and classroom practices, would provide empirical evidence that could potentially bring about recommendations for informed reforms in the content of Jordanian textbooks in general and EFL textbooks in particular (given the prominence of the textbook as the primary, if not the sole, resource in the Jordanian EFL classroom).

Further empirical research is recommended not only on the relationship among the various intelligences but also on the pedagogical implications for these potential relationships and their effect on language learning. The case for the relationship between the verbal/linguistic intelligence and the musical intelligence has been addressed rather briefly, but an examination of this relationship in the Jordanian EFL classroom may prove an endeavor that may constitute a significant contribution to the literature. 


\section{References}

Anvari, S.H., Trainor, L.J., Woodside, J. \& Levy, B.A. (2002). Relations among musical skills, phonological processing, and early reading ability in preschool children. Journal of Experimental Child Psychology, 83, 111-130. doi:10.1016/s00220965(02)00124-8

Armstrong, T. (2001). Multiple intelligences in the classroom. Alexandria, Virginia: ASCD.

Arnold, J., \& Fonseca, M. (2004). Multiple intelligence theory and foreign language learning: A brain-based perspective. International Journal of English Studies, 4 (1), 119-136. Retrieved 17 April 2011 from www.um.es/ijes/vol4n1/06-JArnold\&MCFonseca.pdf

Bas, G. (2008). Integrating multiple intelligences in ESL/EFL classrooms. The Internet TESL Journal, XIV (5). Retrieved 7 May 2010 from http://iteslj.org/Techniques/Bas IntegratingMultipleIntelligences.html.

Berman, M. (2005). A multiple intelligences road to ELT classroom. Trowbridge: Cromwell press.

Bolduc, J. (2009). Effects of a music program on kindergartners' phonological awareness skills 1. International Journal of Music Education, 27(1), 37-47. Retrieved 23 February 2015 from http://ijm.sagepub.com/content/27/1/37.

Bolduc, J., \& Montesinos-Gelet, I. (2005). Pitch awareness and phonological awareness. Psychomusicology, 19, 3-14. doi: 10.1177/0255761408099063

Botelho, M. (2003). Multiple intelligences theory in English language teaching: An analysis of current textbooks, materials and teachers' perceptions. Masters Thesis. Ohio University. Retrieved 29 June 2009 from http://www.ohiolink.edu/etd/ sendpdf.cgi?ohioul079466683.

Chapman, C. (2009). Howard Gardner's multiple intelligences. Retrieved 21 April 2011 from http://www.ascs.net/Art\%20Smarts/Multiple\%20Intelligences.pdf.

Chen, J., Gardner, H., \& Moran, S. (2009). Multiple intelligences around the world. San Francisco: Jossey-Bass.

Fonseca-Mora, M.C., Toscano-Fuentes, C., \& Wermke, K. (2011). The relationship between language aptitude and musical intelligence. Anglistik International Journal of English Studies, 22(1), 101-118. http://dx.doi.org/10.7575/aiac.ijalel.v.3n.3p.26

Gardner, H. (1999). Intelligence reframed: Multiple intelligences for the twenty-first century. New York: Basic Books.

Gardner, H. (2003). Multiple intelligences after twenty years. Retrieved 9 December 2009 from http://www.pz.harvard.edu/PIs/HG_MI after 20 years.pdf.

Gardner, H. (2004). Frames of mind: The theory of multiple intelligences (Tenth Edition). New York: Basic Books.

Gardner, H. (2006). Multiple intelligences. New horizons (First Edition). New York: Basic Books.

Gardner, H., \& Hatch, T. (1996). Multiple intelligences go to school: Educational implications of the theory of multiple intelligences. Retrieved 3 May 2010 from http://www.infed.org/thinkers/gardner.htm.

Gilman, L. (2007). The theory of multiple intelligences. Retrieved 28 April 2010 from http://www.indiana.edu/ intell/mitheory.shtml \#criticism.

Gromko, J. (2012). The effects of music instruction on phonemic awareness in beginning readers. Journal of Research in Music Education, 53, 199-209. doi: $10.1177 / 002242940505300302$ 
Gür, H. (2006). Influences and controls: The national curriculum in England and Turkey. Journal of Turkish Science Education, 3(2). Retrieved 26 September 2009 from http://www.tused.org/internet/ tused/ archive/V3/i2/text/tusedv3i2s7.pdf.

Haines, S. (2009). Action pack 11, grade 11, student's book. London: York Press.

Haines, S. (2010). Action pack 12, grade 12, student's book. London: York Press.

Haley, M. (2004). Learner-centered instruction and the theory of multiple intelligences with second language learners. Teachers College Record, 106(1), 163-180. doi:10.1111/j.1467-9620.2004.00326.x

Hamurlu, M. (2007). The effect of instruction based on multiple intelligences theory on the students' achievements in English and their attitudes towards English at 9th grade at foreign language based high school. Unpublished Master's thesis, Gaziantep University, Gaziantep: Turkey.

Heacox, D. (2002). Differentiating instruction in the regular classroom: How to reach and teach all learners, grades 3-12. Minneapolis, Minnesota: Free Spirit Pub.

Henson, K. (1995). Curriculum development for education reform. New York: Longman.

Hurwitz, I., Wolff, P.H., Bortnick, B.D., \& Kokas, K. (1975). Nonmusical effects of the Kodaly music curriculum in primary grade children. Journal of Learning Disabilities, 8, 167-174. doi:10.1177/002221947500800310

Keddle, J., \& Hobbs, M. (2006). Action pack 8, eighth-grade. London: York Press.

Kerr, J. (1968). Changing the Curriculum. London: University of London Press.

Lambert, V. (2006). Action pack 1, grade one. London: York Press.

Lambert, V. (2008). Action pack 4, grade four. London: York Press.

Lyons, L.M. (2008). The integration of music with reading concepts to improve academic scores of elementary students. Unpublished Doctoral Dissertation, Colorado State University.

Ministry of Education. (2006). The general guidelines and general and specific outcomes for the English language basic and secondary Stages. Amman (Jordan): Directorate of Curricula and School Textbooks.

Moran, M., Kornhaber, M., \& Gardner, H. (2006). Orchestrating multiple intelligences. Educational Leadership, 64(1), 22-27.

Nolen, J. (2003). Multiple intelligences in the classroom. Education, 124(1), 115-119.

Oliva, P. (1997). The curriculum: Theoretical dimensions. New York: Longman.

Omaggio, A. (2001). Teaching language in context (Third edition). Boston: Heinle and Heinle.

Ornstein, A. (1994). The textbook-driven curriculum. Peabody Journal of Education, 69(3), 70-85. doi: 10.1080/01619569409538778

O'Shea, M. (2009). Theory of multiple intelligences. Retrieved 8 December 2009 from http://www.sip.ie/sip065/mitheory.htm.

Palmberg, R. (2002). Catering for multiple intelligences in EFL coursebooks. Humanising language teaching, 4(1). Retrieved 8 December 2009 from http://www.tefl.net/esllesson-plans/multiple-intelligences.htm.

Patel, A.D. (2008). Music, language, and the brain. New York: Oxford University Press.

Patel, A.D. (2012). Language, music and the brain: A resource-sharing framework. In P. Rebuschat, M. Rohrmeier, J. Hawkins \& I. Cross (Eds.), Language and music as cognitive systems (pp. 204-223). Oxford: Oxford University Press.

Patel, A.D., \& Iversen, J.R. (2007). The linguistic benefits of musical abilities. Trends in cognitive sciences, 11, 369-372. doi:10.1016/j.tics.2007.08.003 
Register, D. (2001). The effect of an early intervention music curriculum on pre-reading/ writing. Journal of Music Therapy, 38(3), 239-248. doi: 10.1093/jmt/38.3.239

Russell, S., \& Norvig, P. (2009). Artificial intelligence: A modern approach. New York: Prentice Hall.

Schellenberg, E.G. (2005). Music and cognitive ability. Journal of Psychological Science, 14(6), 317-320. doi: 10.1111/j.0963-7214.2005.00389.x

Shabani, M.B., \& Torkeh, M. (2014). The relationship between musical intelligence and foreign language learning: The case of Iranian learners of English. International Journal of Applied Linguistics and English Literature, 3(3), 26-32. Retrieved 22 February 2015 from http://www.academia.edu/6747353/The_Relationship

Between_Musical_Intelligence_And_Foreign_Language_Learning_The_Case_of_Iran ian_Learners_of_English. doi: 10.7575/aiac.ijalel.v.3n. $3 \mathrm{p} .26$

Sinclair, J., \& Renouf, A. (1988). A lexical syllabus for language learning. Retrieved 13 April 2011 from http://rdues.bcu.ac.uk/publ/Lexical_Syllabus.pdf.

Sleve, R., \& Miyake, A. (2006). Individual differences in second language proficiency. Journal of Psychological Science, 17(8), 675-681. .doi:10.1111/j.14679280.2006.01765.x

Smith, M. (2008). Howard Gardner, multiple intelligences and education. Retrieved 24 November 2009 from http://www.infed.org/thinkers/gardner.htm.

Snider, D. (2001). Multiple intelligences theory and foreign language teaching. Unpublished Doctoral Dissertation. University of Utah.

Stansell, J. (2005). The use of music for learning languages: A review of the literature. Retrieved 19 April 2011 from http://mste.illinois.edu/courses/ci407su02/students/stansell/Jon Stansell The Use of_Music in_Learning_Languages.pdf.

Teitlebaum, K. (2008). Curriculum. In S. Mathison \& W. Ross (Eds.) Battleground schools (pp. 168-177). Westport, Connecticut: Greenwood Press.

Thompson, H. (2009). Standard intelligence vs. multiple intelligences. Retrieved 14 November 2009 from http://hmt.myweb.uga.edu/we bwrite/printable2.htm.

Weiss, S. (1999). Extra! Extra! Interview with Howard Gardner. NEAToday Online. Retrieved 14 November 2009 from http://www.nea.org/neatoday/9903/gardner.html.

Wilson, L. (2006). Curriculum-different types. Retrieved 5 April 2011 from http://www.uwsp.edu/education/lwilson/curric/curtyp.htm.

Wright, A., Betteridge, D., \& Buckby, M. (2005). Games for language learning. New York: Cambridge University Press.

\section{Authors' Biodata}

Dr. Taghrid Al-Omari is currently a part-time instructor at the Department of English Language and Linguistics at Jordan University of Science and Technology (Irbid, Jordan).

Dr. Ruba Bataineh is a professor of TESOL at the Department of Curriculum and Instruction at Yarmouk University (Irbid, Jordan). Her research interests include sociolinguistics, pragmatics, literacy, CALL, and teacher education. Professor Bataineh has published extensively in renowned international and regional journals. She is also a member of the editorial and/or review boards for a number of regional and international journals. Professor Bataineh has recently won the Best Researcher Award at Prince Sultan University College for Women. Dr. Oqlah Smadi is a professor of applied linguistics at the Dept of Curriculum and Instruction at Yarmouk University (Irbid, Jordan).

Email: taghridalomari@yahoo.com (principal author) 
To cite this article:

Al-Omari, T., Bataineh, R., \& Smadi, O. (2015). Potential inclusion of multiple intelligences in Jordanian EFL textbooks: A content analysis. Bellaterra Journal of Teaching \& Learning Language \& Literature, 8(1), 60-80. http://dx.doi.org/10.5565/rev/jtl3.597 